\title{
UPAYA MENINGKATKAN PRESTASI BELAJAR MATA PELAJARAN IPA RANGKAIAN SERI DAN RANGKAIAN PARALEL MELALUI METODE EKSPERIMEN SISWA KELAS VI SD N 10 UJAN MAS
}

\author{
Daliyawati
}

\begin{abstract}
Abstrak
Setelah dilakukan observasi dan evaluasi dalam pembelajaran yang hasilnya digunakan sebagai bahan refleksi atas apa yang terjadi pada mata pelajaran Sains kelas VI meteri Rangkaian seri dan rangkaian paralel diketahui ketidakberhasilan mencapai standar keberhasilan yang ditetapkan sebesar 75,00 serta adanya ketidakaktifan dan ketidakpahaman siswa pada konsep rangkaian seri dan rangkaian paralel sehingga diperlukan adanya perbaikan pembelajaran. Metode eksperimen PTK diberikan untuk memberi kesempatan kepada peserta didik agar dapat mengalami sendiri atau melakukan sendiri, mengikuti suatu proses, mengamati suatu objek, menganalisis, membuktikan dan menarik kesimpulan sendiri tentang suatu objek, keadaan atau proses sesuatu dan diharapkan mampu memperbaiki hasil pembelajaran. Secara umum hasil Penelitian Tindakan Kelas meningkatkan pemahaman tentang rangkaian seri dan rangkaian paralel dalam kegiatan belajar mengajar (KBM) mata pelajaran Sains pada kelas VI SDN 10 Ujan Mas dengan mengoptimalkan penggunaan metode eksperimen sebagai alternatif strategi pembelajaran. Dari analisis data nilai hasil evaluasi siklus II jika dibanding dengan siklus I terdapat kenaikan yang sangat berarti. Pada siklus I dari 20 siswa diperoleh nilai rata-rata kelas 65.5, nilai 70 keatas dengan 12 siswa atau 60\%, siswa mendapat nilai dibawah 6 dan 8 siswa atau 40\%, sedangkan pada siklus II dari 20 siswa diperoleh nilai rata-rata kelas 8,8 dengan 19 siswa nilai 70 keatas atau 95\% siswa mendapat nilai 60 hanya 1 siswa atau 5\%, maka pelaksanaan siklus II telah berhasil meningkatkan prestasi belajar rangkaian seri dan rangkaian paralel di SD Negeri SDN 10 Ujan Mas dengan standar keberhasilan 75,00. Hal ini menunjukkan bahwa metode Eksperimen yang digunakan peneliti terbukti dapat meningkatkan aktifitas dan hasil belajar siswa kelas VI SDN 10 Ujan Mas Tahun Pelajaran 2014/2015
\end{abstract}

Kata Kunci : Metode eksperimen, meningkatkan Hasil Belajar.

\section{PENDAHULUAN}

Pendidikan menurut Driyakarya (1980) adalah upaya memanusiakan manusia muda. Pengangkatan manusia muda ke taraf insani harus diwujudkan di dalam seluruh proses atau upaya pendidikan. Pengertian tersebut mirip dengan pendapat G. Thompson (1957) yang menyatakan bahwa pendidikan adalah pengaruh lingkungan atas individu untuk menghasilkan perubahan-perubahan yang tetap di dalam kebiasaan-kebiasaan, pemikiran, sikap-sikap, dan tingkah laku. Tilaar (1999:28) merumuskan hakikat pendidikan sebagai suatu proses menumbuhkembangkan eksistensi peserta didik yang memasyarakat, membudaya, dalam tata kehidupan yang berdimensi lokal, nasional, dan global.

Atas dasar pemahaman tentang beberapa definisi pendidikan maka dapat didefinisikan Pendidikan Sekolah Dasar bukan hanya memberi bekal kemampuan intelektual dasar dalam 
membaca, menulis dan berhitung saja melainkan juga sebagai proses mengembangkan kemampuan dasar peserta didik secara optimal dalam aspek intelektual, sosial, dan personal, untuk dapat melanjutkan pendidikan di SLTP atau yang sederajat. Pembelajaran yang berkualitas merupakan suatu interaksi semua komponen yang terlibat secara efektif dan efisien dalam pencapaian tujuan. Pembelajaran akan berkualitas jika tujuan, metode, media, materi, siswa, sumber belajar, dan pembelajaran dapat berinteraksi bermakna dan dapat menambah nilai lebih kepada siswa dan guru.

Rangkaian seri dan rangkaian paralel merupakan pokok bahasan yang harus dipelajari oleh siswa kelas VI SD Negeri 10 Ujan Mas, dan diharapkan bermanfaat bagi diri siswa sendiri dan orang lain. Berdasarkan pengamatan dan pengalaman bahwa pembelajaran rangkaian seri dan rangkaian paralel kurang diminati oleh siswa kelas VI SD Negeri 10 Ujan Mas, hal ini dikarenakan pembelajarannya yang hanya berisi teori-teori tanpa membuktikan kebenarannya. Belum ada usaha inovasi dalam pembelajarannya. Aktivitas siswa dalam memperoleh pengetahuan tentang rangkaian seri dan rangkaian paralel hanya melalui metode ceramah dan tanya jawab. Hasil yang diperoleh adalah bertambahnya pengetahuan tentang rangkaian seri dan paralel dari pembelajar berdasarkan pengetahuan guru dan buku sumber. Pada akhirnya siswa belum bisa mempraktekkan untuk membuat rangkaian seri dan rangkaian paralel berdasarkan pengetahuan dan pengalamannya tantang rangkaian seri dan rangkaian paralel. Tujuan pembelajaran tentang rangkaian seri dan rangkaian paralel akan tercapai jika menggunakan metode pembelajaran yang tepat pada siswa kelas VI SD Negeri 10 Ujan Mas, dan ditingkatkan sesuai dengan kondisi yang ada. Terutama aktivitas belajar siswa dalam memperoleh pengetahuan dan pengalaman tentang rangkaian seri dan rangkaian paralel. Oleh karena itu diperlukan suatu usaha untuk mencari, menetapkan dan mengembangkan metode pembelajaran yang tepat dan sesuai dengan kondisi siswa.

Salah satu metode yang dapat diterapkan adalah metode eksperimen atau percobaan. Metode eksperimen atau percobaan merupakan metode mengajar yang sangat efektif dalam menolong siswa-siswa mencari jawaban atas pertanyaan bagaimana cara membuatnya? Terdiri dari alat dan bahan apasaja? Cara mana yang paling baik? Dengan eksperimen dimaksudkan bahwa guru atau siswa mencoba mengerjakan sesuatu serta mengamati proses dan hasil percobaan itu.

Metode eksperimen atau percobaan diartikan sebagai cara belajar mengajar yang melibataktifkan peserta didik dengan mengalami dan membuktikan sendiri proses dan hasil percobaan itu. Dengan metode eksperimen siswa aktif mengambil bagian berbuat untuk dirinya sendiri. Siswa tidak hanya melihat seseorang menyelesaikan sesuatu eksperimen tetapi juga berbuat, ia memperoleh kepandaian-kepandaian yang diperlukan. Dan siswa mendapat kesempatan yang sebagian besar untuk melaksanakan langkah-langkah dalam cara berpikir ilmiah. Ramalan-ramalan atau hipotesahipotesa dapat diuji kebenarannya dengan mengumpulkan data-data hasil observasi kemudian dengan menafsirkannya dan terakhir siswa membuat kesimpulan-kesimpulan dari hasil observasi tersebut.

Apabila menggunakan metode eksperimen maka kita harus menerangkan sejelas-jelasnya tujuan pembelajaran pada siswa, sehingga siswa mengetahuipertanyaan yang perlu dijawab dengan eksperimen. Guru juga harus membicarakan bersama dengan siswa prosedur atau langkah-langkah yang dianggap sebaikbaiknya untuk memecahkan masalah dalam eksperimen serta bahan-bahan yang diperlukan, variabel yang perlu dikontrol dan hal-hal yang perlu dicatat. Guru juga harus menolong siswa untuk memperoleh bahan-bahan yang diperlukan. Setelah eksperimen selesai siswa membandingbandingkan hasilnya dengan hasil eksperimen 
orang lain dan mendiskusikan bila ada perbedaan-perbedaan atau kekeliruan.

Dengan demikian untuk meningkatkan hasil belajar IPA tentang rangkaian seri dan rangkaian paralel pada siswa kelas VI SD Negeri 10 Ujan Mas dapat melalui Penelian Tindakan Kelas (PTK) dengan menerapkan metode eksperimen. Metode eksperimen membuat peserta didik percaya pada kebenaran kesimpulan percobaannya sendiri dari pada hanya menerima kata guru atau buku sumber .

\section{METODE}

Penelitian ini merupakan teknik penelitian tindakan kelas (PTK). Penelitian tindakan kelas adalah suatu bentuk penelitian yang bersifat reflektif dengan menggunakan tindakan agar dapat memperbaiki pembelajaran di kelas (Kasbolah,1999:4). Penelitian tindakan kelas adalah penelitian tindakan dalam bidang pendidikan yang melaksanakannya di dalam kelas dengan tujuan untuk memperbaiki dan meningkatkan kualitas pembelajaran.

Dalam penelitian tindakan kelas ini, guru mempunyai peranan penting dimana guru terlibat penuh secara langsung dalam setiap proses perancanaan, tindakan, observasi dan refleksi (Kasbolah, 1999:122). Prosedur penelitian yang digunakan adalah prosedur penelitian tindakan kelas model Kemmis dan Taggart ( Kasbollah, 1998:7). Model ini digambarkan bahwa penelitian tindakan kelas adalah penelitian yang merupakan serangkaian langkah-langkah. Setiap langkah terdiri dari empat komponen, yakni : (1) rencana (Planning), yaitu tindakan yang akan dilakukan untuk memperbaiki, meningkatkan atau perubahan perilaku, dan sikap sebagai solusi; (2) Tindakan (Action) yaitu apa yang harus dilakukan peneliti sebagai upaya perbaikan peningkatan atau perubahan yang diinginkan; (3) Observasi (Observation) yaitu mengamati atas hasil atau dampak dari tindakan-tindakan yang dilaksanakan oleh siswa; dan (4) Refleksi (Reflection) yaitu tahap pengkajian melihat dan mempertimbangkan atas hasil dan proses dari setiap tindakan berdasarkan hasil refleksi.

Dalam pelaksanaan penelitian tindakan kelas ini dimulai rencana tindakan, observasi dan refleksi, merupakan tahapan yang saling berhubungan antara yang satu dengan yang lainnya. Pada masing-masing tahapan meliputi proses penyempurnaan yang didasarkan atas hasil dari masing-masing proses. Dimulai dari rencana lalu diadakan tindakan dan observasi kemudian diadakan refleksi.

Pada tahap rencana yang dilakukan adalah menyusun Rencana Pelaksanaan Pembelajaran (RPP), menyiapkan alat peraga atau media serta instrumen. Setelah itu baru dilanjutkan untuk melaksanakan rencana yang telah dipersiapkan, selanjutnya pada tahap observasi dilakukan pengamatan proses pembelajaran dari awal sampai akhir, yang diobservasikan adalah kegiatan siswa selama kegiatan pembelajaran berlangsung. Tahap refleksi dengan menganalisis masalah, menganalisis model pembelajaran dan menganalisis kegiatan pembelajaran.

Setiap tahapan berfungsi dengan saling berhubungan karena masing-masing tahapan meliputi proses penyempurnaan yang berdasarkan pada hasil setiap tahapan tersebut. Pelaksanaan setiap tahapan dilaksanakan secara terus-menerus dari awal sampai akhir penelitian. Dalam penelitian tindakan kelas ini terdiri dari tiga siklus.

Subyek penelitian ini adalah siswa kelas VI SD Negeri 10 Ujan Mas dengan jumlah murid 20, terdiri dari 7 siswa laki-laki dan 13 siswa perempuan dengan kemampuan prestasi belajar yang bervariasi. Pemilihan sekolah ini bertujuan untuk memperbaiki dan meningkatkan proses pembelajaran di sekolah tersebut.

Penelitian ini dilaksanakan pada semester genap tahun ajaran 2014/2015, pada bulan Januari sampai dengan Maret. Penelitian Tindakan Kelas ini dilaksanakan melalui dua siklus untuk melihat peningkatan hasil belajar dan aktivitas siswa dalam mengikuti mata pelajaran IPA melalui metode pembelajaran eksperimen. Adapun jadwal pelaksanaan 
penelitian ini adalah pada Januari 2015 (pelaksanaan Siklus I) dan pada 11 Maret 2015 (pelaksanaan Siklus II) yang masing-masing siklus dilaksanakan dalam 2 jam pelajaran.

Instrumen adalah sarana penelitian (berupa tes dan nontes) untuk memperoleh data dalam kegiatan pengumpulan, pengolahan, analisis, dan penyajian data. Instrumen penelitian yang digunakan dalarn kegiatan penelitian tindak kelas ini adalah dua jenis yaitu instumen pembelajaran dan instumen pengumpulan data.

Instrumen pembelajaran yang digunakan dalam penilaian tindakan kelas ini, yaitu: Rencana Pelaksanaan Pembelajaran (RPP), Lembar Kerja Siswa (LKS), dan tes individu. RPP merupakan alat atau pegangan bagi guru (peneliti) dalam melaksanakan pembelajaran, yang di dalamnya terdiri dari standar kompetensi, kompetensi dasar, indikator, tujuan pembelajaran, materi pokok, langkah-langkah pembelajaran, alokasi waktu dan evaluasi atau tes. Sedangkan (LKS) merupakan serangkaian pertanyaan atau perintah yang harus dikerjakan oleh siswa dalam kegiatan pembelajaran baik di kelas atau di luar kelas. Dengan menggunakan alat peraga merupakan sesuatu hal yang besifat abstrak dapat disajikan dalam bentuk benda konkrit yang dapat dilihat, dipegang, diputar balikan sehingga dapat lebih mudah dipahami.

Instrumen untuk memperoleh data proses dan hasil penelitian menggunakan 2 metode, yaitu: (1) Metode tes, Tes diberikan setelah kegiatan inti, dalam bentuk tes tulis dan diperoleh nilai rata-rata kelas 62. Hasil ini mengalami peningkatan dari pada sebelum perbaikan pembelajaran. Namun belum mencapai standar keberhasilan yang ditetapkan sebesar 75,00; (2) Metode observasi, Dalam pelaksanaan observasi/pengamatan kegiatan peneliti dalam mengajar selama proses perbaikan pembelajaran berlangsung, peneliti dibantu oleh teman sejawat. Berdasarkan catatan pengamatan teman sejawat pada pelaksanaan perbaikan pembelajaran kegiatan diskusi kurang optimal karena tidak adanya arahan dan panduan bagi siswa dalam berdiskusi sehingga keaktifan siswa masih rendah juga kurangnya pemberian contoh rangkaian seri dan rangkaian paralel yang mengakibatkan rendahnya tingkat pemahaman siswa.

\section{HASIL}

Setelah melalui serangkaian tahapan proses penelitian, didapat seperangkat data yang dapat dianalisa untuk mengetahui tingkat kebersilan Penelitian Tindakan Kelas (PTK) terhadap pemahaman konsep rangkaian seri dan rangkaian paralel pada kelas VI SD Negeri 10 Ujan Mas dengan menggunakan metode Eksperimen.

\section{Siklus I}

Sesuai dengan salah satu tujuan penelitian yaitu untuk mendapatkan gambaran nyata tentang usaha yang dilakukan peneliti untuk meningkatkan pemahaman konsep rangkaian seri dan rangkaian paralel dengan menggunakan metode eksperimen maka tahapan-tahapan perbaikan pembelajaran yang telah dilaksanakan peneliti pada hari Senin, 19 Januari 2014 pukul 08.15 sampai dengan 09.15 WIB dapat diuraikan sebagai berikut:

\section{Tahap Pertama/ Kegiatan Awal}

Peneliti melakukan apersepsi dan menyampaikan tujuan pembelajaran yang akan dicapai siswa. Pada tahap ini peneliti hendaknya dapat memberikan motivasi atau dorongan serta stimulan agar siswa mampu berperan secara aktif dalam kegiatan pembelajaran dan tertarik untuk mengembangkan kemampuan dirinya melalui aktivitas pembelajaran.

\section{Tahap Kedua/ Kegiatan Inti}

Peneliti masuk pada tahap proses menyampaikan materi pembelajaran yaitu melakukan eksperimen/ percobaan rangkaian seri danrangkaian paralel dengan menggunakan media/ alat peraga secara tepat dan sistematis. Peneliti memberikan kesempatan pada siswa untuk ikut serta dalam pelaksanaan eksperimen/ percobaan agar siswa aktif dan merasakan 
ketertarikan dalam pembelajaran selama pelaksanaan eksperiman/ percobaan peneliti juga memberikan penugasan kelompok pada siswa untuk mencatat kejadian-kejadian yang diamatinya. Penugasan ini akan melatih dan membiasakan siswa untuk dapat berperan aktif dalam pembelajaran.

\section{Tahap Ketiga/ Penutup}

Peneliti melakukan kegiatan evaluasi dengan memberikan latihan soal yang akan melatih dan meningkatkan kemampuan pemahaman siswa terhadap materi yang dipelajari, peneliti juga membimbing siswa untuk membuat kesimpulan berdasarkan kegiatan pembelajaran yang baru saja dilakukan bersama secara reflektif akan membantu siswa kelas VI untuk lebih memahami dan mengenali potensi diri masing-masing, guna pengembangan lebih lanjut sebagai kegiatan akhir peneliti memberikan pekerjaan rumah (PR).

Selama proses kegiatan belajar mengajar (KBM) dilakukan observasi dengan hasil sebagai berikut: (1) aspek persiapan peneliti yang telah terlaksana dengan baik; (2) aspek penyajian yang telah terlaksana cukup baik namun ada kelemahan yaitu masih kurangnya contoh penerapan rangkaian seri dan rangkaian paralel; dan (3) aspek penampilan peneliti yang telah terlaksana dengan baik.

Selain data hasil observasi di atas, berikut ini data peningkatan hasil belajar siswa tentang rangkaian seri dan rangkaian paralel. Analisis nilai hasil evaluasi Siklus I mendapat nilai rerata 65,5. Dari analisis data nilai hasil evaluasi siklus I dari 20 siswa diperoleh nilai rata-rata kelas 65,5 dengan 17 siswa mendapat nilai dibawah 75 dan 3 siswa mendapat nilai di atas 75 maka pelaksanaan siklus I ini belum dapat mencapai standar keberhasilan yang ditetapkan yaitu 75,00.

\section{Siklus II}

Dari hasil analisis data-data pelaksanaan siklus I dapat diketahui ketidakberhasilan mencapai standar keberhasilan yang ditetapkan sebesar 75,00 dan adanya kelemahan dalam pelaksanaan perbaikan yaitu tidak adanya panduan pelaksanaan diskusi dan pemberian contoh rangkaian seri dan rangkaian paralel. Untuk itu dilaksanakan perbaikan pembelajaran siklus II dengan menekankan pada panduan pelaksanaan diskusi dan memperbanyak contoh penerapan rangkaian seri dan rangkaian paralel.

Tahapan-tahapan pelaksanaan siklus II yang telah dilaksanakan peneliti pada hari Selasa 11 Maret 2014 pukul 08.15 sampai dengan 09.15 WIB dapat dicermati dalam uraian singkat di bawah ini :

\section{Tahapan Pertama/ Kegiatan Awal}

Pada tahap ini peneliti melakukan tanya jawab sebagai kegiatan apersepsi yang dapat memberikan dorongan / motivasi serta stimulan agar siswa mampu berperan aktif dalam pembelajaran dan tertarik untuk mengembangkan kemampuan dirinya melalui aktivitas pembelajaran. Peneliti juga menyampaikan tujuan pembelajaran yang ingin dicapai agar siswa siap mengikuti pembelajaran

\section{Tahapan Kedua/ Kegiatan Inti}

Peneliti melakukan percobaan/ eksperimen untuk meningkatkan hasil belajar siswa tentang rangkaian seri dan rangkaian paralel, selanjutnya memberikan beberapa permasalahan yang didiskusikan dengan kelompok masing-masing untuk menentukan jenis rangkaian seri dan rangkaian paralel. Pada penugasan kelompok ini akan melatih dan membiasakan siswa untuk aktif menyampaikan gagasan / pendapat juga memecahkan suatu masalah sehingga dengan sendirinya kemampuan pemahaman siswa akan meningkat dan hasil belajarnyapun akan meningkat.

\section{Tahapan Ketiga/ Kegiatan Akhir}

Peneliti melakukan kegiatan evaluasi dengan memberikan latihan soal yang akan melatih dan meningkatkan prestasi hasil belajar terhadap materi yang telah dipelajari. Peneliti juga membimbing siswa untuk membuat kasimpulan. Kegiatan-kegiatan pada tahap ini secara reflektif akan membantu siswa kelas VI untuk mengembangkan lebih lanjut.

Hasil tes sesudah diadakan kegiatan siklus II, nilai rata-rata siklus II adalah 89,5. Dari 
analisis data nilai rata-rata siswa adalah 89,5, hasil belajar evaluasi siklus II dari 20 siswa diperoleh nilai rata-rata kelas 80 dengan 17 siswa atau $85 \%$ siswa mendapat nilai dibawah 75,00 dan 3 siswa atau $15 \%$ siswa mendapat nilai di atas 75,00 maka pelaksanaan siklus II telah berhasil meningkatkan prestasi belajar rangkaian seri dan rangkaian paralel di SD Negeri 10 Ujan Mas dengan standar keberhasilan 75,00.

\section{PEMBAHASAN}

Hasil penelitian untuk meningkatkan prestasi belajar tentang rangkaian seri dan rangkaian paralel dengan menggunakan metode eksperimen / percobaan di SD Negeri 10 Ujan Mas menurut peneliti telah tepat mengenai sasaran. Pada siklus I, kegiatan pembelajaran yang dilakukan peneliti meliputi : kegiatan awal, kegiatan Inti dan kegiatan penutup telah terlaksana dengan baik dan sesuai dengan perencanaan. Penerapan metode eksperimen sedikit banyak telah menciptakan suatu kondisi yang menjadikan siswa belajar dan aktif dalam proses pembelajaran yang pada akhirnya dapat berimplementasi langsung pada hasil evaluasi siswa.

Hal ini sesuai dengan penjelasan Gagne and Berliner (Abin Syamsudin, 1997) bahwa “ Peran, tugas dan tanggung jawab guru adalah sebagai perencana (planner), pelaksana (organiser), dan penilai (evaluator). Guru mempunyai peran penting untuk merencanakan, menciptakan kondisi yang merangsang dan menggerakkan siswa belajar dengan menggunakan metode yang tepat dalam kegiatan pembelajaran dan juga pelaksanaan evaluasi untuk mengetahui tingkat keberhasilan mengenai aspek keefektifan proses maupun kualifikasi produk.

Penggunaan metode eksperimen pada mata pelajaran Sains telah dapat menyajikan materi dengan mempertunjukkan secara langsung objeknya atau cara malakukan sesuatu untuk mempertunjukkan rangkaian seri dan rangkaian paralel. Metode ini juga telah memberikan pengalaman langsung paa siswa dengan mengarahkan kegiatannya untuk " mencari tahu " dan "berbuat" sehingga siswa memperoleh pemahaman yang lebih mendalam tentang rangkaian seri dan rangkaian paralel.

Metode eksperimen yang diterapkan Peneliti telah meningkatkan keaktifan siswa dalam proses pembelajaran karena metode ini memberikan kesempatan seluas-luasnya untuk menyampaikan pendapat dan bertukar pikiran tentangpengalaman dan pengetahuan yang diperolehnya pada saat melakukan eksperimen guna mencapai kesepakatan bersama.

Seperti siklus sebelumnya, pelaksanaan siklus II juga telah terlaksana dengan baik serta mampu meningkatkan dan menggairahkan pengelolaan kegiatan pembelajaran. Penggunaan metode eksperimen telah membuat siswa belajar secara efektif dan efisien. Mengutip pernyataan Slamet (1987:2) "Belajar adalah suatu proses usaha yang dilakukan individu untuk memperoleh suatu usaha perubahan tingkah laku yang baru secara keseluruhan sebagai hasil pengalaman individu itu sendiri dalam interaksi dengan lingkungannya". Jadi proses belajar terjadi bila dapat memberikan pengalaman langsung pada siswa dalam interaksi dengan lingkukngannya. Dengan metode eksperimen telah memberikan kesempatan seluas-luasnya pada siswa untuk memperoleh pengalaman langsung dalam interaksi denga lingkungan maupun interaksi dengan teman sebaya. Interaksi ini telah menimbulkan motivasi yang tinggi dalam diri siswa untuk dapat memahami materi lebih dalam lagi yang ditunjukkan dengan keaktifan siswa dalam melakukan eksperimen.

Keberhasilan pelaksanaan PTK ini tidak terlepas dari upaya peneliti memilih metode yang tepat / efektif dan efisien dimana selama proses pembelajaran dapat tercipta situasi pengajaran yang benar-benar menyenangkan, mendukung kelancaran proses belajar dan tercapainya prestasi belajar yang memuaskan

\section{SIMPULAN}


Sejalan dengan materi dalam rumusaß. masalah dan tujuan penelitian, secara khusus setelah melakukan kegiatan Penelitian Tindakan Kelas (PTK) dengan subyek penelitian siswa kelas VI SD Negeri 10 Ujan Mas, Peneliti sampai pada suatu kesimpulan bahwa melalui penggunaan metode eksperimen dari sekian banyak ragam dan bentuk alternatif metode pembelajaran dapat meningkatkan keaktifan dan pemahaman tengtang rangkaian seri dan rangkaian paralel yang telah berimplementasi langsung pada hasil prestasi belajar siswa kelas VI SD Negeri 10 Ujan Mas dengan peningkatan yang cukup signifikan.

Secara umum hasil Penelitian Tindakan 1 . Kelas (PTK) meningkatkan pemahaman tentang rangkaian seri dan rangkaian paralel dalam kegiatan belajar mengajar (KBM) mata pelajaran Sains pada kelas VI SD Negeri 10 Ujan Mas dengan mengoptimalkan penggunaan metode eksperimen sebagai alternatif strategi pembelajaran disimpulkan :

1. Apabila ada siswa yang tidak menguasar. materi pelajaran yang dipelajari, maka menjadi tugas guru untuk mencari faktor penyebabnya dan cara mengatasinya demi peningkatan kemampuan pemahaman dan prestasi belajar siswa.

2. Penggunaan metode eksperimen dalam pembelajaran secara nyata dapat meningkatkan kemampuan siswa dalam memahami suatu proses yang tidak cukup ${ }^{4}$ hanya dengan membayangnkan saja. Hal ini dapat dilihat dari hasil analisis data nilai rata-rata siswa adalah 89,5, hasil belajar evaluasi siklus II dari 20 siswa diperoleh nilai rata-rata kelas 80 dengan 17 siswa atau $85 \%$ siswa mendapat nilai dibawah 75,00 dan 3 siswa atau $15 \%$ siswa mendapat nilai di atas 75,00 maka pelaksanaan siklus II telah berhasil meningkatkan prestasi belajar rangkaian seri dan rangkaian paralel di SD Negeri 10 Ujan Mas dengan standar keberhasilan 75,00.
Peningkatkan kemampuan pemahaman dan prestasi belajar siswa tidak terlepas dari peran aktif siswa dalam proses pembelajaran.

\section{SARAN}

Berpijak pada pengalaman singkat peneliti menggunakan metode eksperimen sebagai alternatif metode pembelajaran pada kegiatan belajar mengajar (KBM) mata pelajaran IPA pada siswa kelas VI SD Negeri 10 Ujan Mas, Peneliti memberikan beberapa saran kepada pihak-pihak yang terlibat dalam pendidikan yang meliputi :

Kepada rekan-rekan sejawat yang ingin meningkatkan pemahaman serta prestasi belajar siswanya, apabila situasi dan kondisi yang berkembang di sekolah atau lingkungan pendidikannya relatif mempunyai kesamaan dengan apa yang ada di sekolah peneliti, maka disarankan untuk menggunakan metode ini sebagai strategi pembelajaran.

Kepada Kepala Sekolah dan jajaran pengelola sekolah disarankan agar memberikan dukungan dan fasilitas rekan-rekan guru dalam memperbaiki dan mengembangkan pembelajaran untuk meningkatkan prestasi belajar siswanya.

3. Kepada orang tua dan wali murid hendaknya mempunyai kepedulian yang tinggi dan pro aktif dengan proses pembelajaran yang dilakukan di sekolah.

Kepada semua siswa hendaknya senantiasa tidak bosan dan tidak berhenti untuk belajar meningkatkan kemampuan pemahaman dan keterampilannya dalam semua mata pelajaran yang dipelajari di sekolah.

\section{DAFTAR PUSTAKA}

Hamalik, Oemar. (1995).Kurikulum dan Pembelajaran. Jakarta: Bumi Aksara.

Kasbuloh, Kasihani. 1998/1999.Penelitian Tindakan Kelas. Jakarta: Depdikbud, Kurikulum SD Negeri 10 Ujan Mas, 2014 
Daliyawati

Sumantri, Mulyani. dan Permana, Johar. (1998). Strategi Belajar Mengajar. Jakarta : Departemen Pendidikan dan Kebudayaan.

Syamsudin, Abin. dan Budiman, Nandang. (2005). Profesi Keguruan 2. Jakarta : Universitas Terbuka.

Wahyudin, Dinn., Supriadi, D., dan Abdulhak, Ishak. (2003). Pengantar Pendidikan. Jakarta: Universitas Terbuka.

Wardani, IG. A. K., Wihardit, K., dan Nasoetion, N. (2000). Penelitian Tindakan Kelas. Jakarta : Universitas Terbuka.

Winataputra, Udin S., dkk. (2002). Strategi Belajar Mengajar. Jakarta: Universitas Terbuka. 